\title{
DEVELOPING CHARACTER ON THE ENVIRONMENT TO THE CHILDHOOD EDUCATION
}

\author{
Sri Rahayu ${ }^{1}$, Mapilindo ${ }^{2}$, Susi Masniari Nasution ${ }^{3}$ \\ Faculty Teacher and Tranning Education Asahan University ${ }^{123}$ \\ srir99774@gmail.com¹,dodomicke@yahoo.co.id ${ }^{2}$,suzymasniari@yahoo.com³
}

\begin{abstract}
ABSTRAK
The research has a purpose to know the learning how to develop the character of the 5-6 years old in childhood of North Sumatera. The method in this research was descriptive in form of qualitative. Actually, the subjects of research were the teachers and the children it the age of 5 to 6 in group B. The techniques and tools of data collection were direct communication, observation, document of study. The result of the research showed that the natural intelligence about pre-school environment has been applied effectively. The natural intelligence was implemented everyday through habitual way of engaging the children actively in playing activities. Therefore, the resistance of character activity was around the media which showed the weakness in stimulating the children activities and fulfilling the standard of playing media in childhood Education.
\end{abstract}

\section{Keywords: Character}

\section{INTRODUCTION}

Early childhood education (ECD) is an education before level education base which is a development efforts aimed at children from birth to the age of six years will be undertaken through the provision of stimuli education to assist the growth and development of the physical and spiritual so that children have the readiness to enter education further, held in formal, non-formal and informal. In the Law of the Republic of Indonesia Number 20 Year 2003 on National Education System, chapter 1, verse 14, states "early childhood education (ECD) is a development efforts aimed at children from birth to the age of six years are accomplished by providing stimulus education to help the growth and development of children physically and mentally in order to have the readiness to enter further education.The early age is the figure of people who are undergoing a process of rapid and fundamental developments for the next life Education in early childhood basically covering all efforts and actions taken by educators and parents in the process of care, upbringing and education of children by creating an atmosphere and an environment where children can expose experience gives him a chance to know and understand the learning experience gained of the environment, through observing, imitating and experimenting that goes repeatedly and involve the potential and children character Education in early childhood is one of the organization.

Education that focuses intellect (the intellect, creativity, emotional intelligence, spiritual intelligence) character need to be taught and inculcated from early childhood, which is between $0-6$ years. In accordance with the theory of brain development, because early childhood is the child more quickly absorbed what was applied by teachers or embed the memory of children. The role of parental influence naturalist, because it is the parents and early childhood that is having an important role in instilling values character. Parents and early childhood teachers should have enough knowledge about the values characterthat they can provide theoretical knowledge and real example to the children.

So from an early age the kids have got knowledge about the environment and how to preserve the environment with the practice of direct or concrete examples can encourage more foster children affection to the environment. Examples of such small, nurturing environment (planting, watering, weeding, fertilizing, loving plants while explaining to the child). Maintaining and loved animals, clean up the environment, dispose of waste in place, they get used to not uproot plants roughly or carelessly. The habits are instilled early on this would be an embedded memory in the brain of children so that their children will consistently practice the values naturalist . Based on observations conducted by researchers, namely the attitude of children who tend to be ignorant of what is in the preschool environment, environmental hygiene kindergartens as well as the benefits of the existing plants in the preschool yard. Examples of such small, nurturing environment (planting, watering, weeding, 
fertilzing, loving plants wnile explaining to the cnila). IVaintaining and loved animais, clean up the environment, dispose of waste in place, they get used to not uproot plants roughly or carelessly. The habits are instilled early on this would be an embedded memory in the brain of children so that their children will consistently practice the values naturalist. based on observations conducted by researchers, namely the attitude of children who tend to be ignorant of what is in the preschool environment, environmental hygiene kindergartens as well as the benefits of the existing plants in the preschool yard. For example, when eating candy and throw away the candy shell is not in place. This is what makes researchers want to investigate more about the naturalist conducted as a research site is also implementing naturalist intelligence about the environment to children aged 5-6 years, as a provision to them get ready to enter further education. Therefore, researchers intend to examine the "character about the neighborhood preschool at the age of 5-6 years in kindergarten MiftahulJannah.

According Biecher and Snowman in Soefandi and Pramoedya (2009) early childhood is children who are in the age of 3-6 years. At this time the process of growth and development of children is unique, meaning that it has the characteristics of growth and physical development, motor, cognitive or intellectual, social, emotional and language.Gadner in Sujiono (2009) states that intelligence is the ability to solve problems, create a product that is valuable in one or several cultural environment .Education in early childhood is one of providing education that focuses on laying the basis to several directions below: ) Growth and physical development (fine and gross motor coordination). 2) Intelligence (intellect, creativity, emotional intelligence, spiritual intelligence). 3)socioemotional (attitudes and behavior and religion) language and communication, tailored to the uniqueness and the developmental stages through which early childhood (Maimunah, 2012) Gadner in Sujiono (2009) was originally explained 7 (seven) aspects of intelligence that indicates different intellectual competence, and then add it to 8 (eight) aspects of intelligence, which is composed of linguistic, logical-mathematical intelligence, physical intelligence / kinesthetic, spatial intelligence, musical intelligence, intrapersonal intelligence, interpersonal intelligence, character, but in the application in Indonesia increased to 9 (nine), that spiritual intelligence. The naturalist intelligence is the ability to perceive forms and linking objects that exist.Skill know and explore species (flora, fauna) in the environment, recognize the existence of the species, mapping the relationship between some species and other natural phenomena. Children with prominent naturalist has a great interest in the environment, including the animals, at a very early age. They enjoy objects and stories relating to natural phenomena such as the occurrence of clouds and rain, the origin of the animal, plant growth, and the solar system in IndraSoefandi (2009).

Every child is born with a number of potential that is passed on from generation before it. Potential default is genetic (Heredity factor), is actually an early ability possessed by every individual who is born to adapt to its environment (Sujiono and Sujiono 2004). In order for children to develop optimally, the innate potential need is grown through a variety of stimulation and the efforts of the neighborhood. Children need to have the opportunity to develop other aspects of multiple intelligences, such as spatial, musical, kinesthetic, naturalistic, intrapersonal and interpersonal. Most children have a number of intelligence and different learning styles and can be displayed in many different ways and in accordance with the circumstances. Behavior naturalist in learning activities in the classroom, namely 1) Take out the trash in its place. 2) Observing the natural process of mixing colors. 3) Observing the various types of plants. 4) Know the kind / type of animal. 5) Know the limbs of animals another member legs and head (eyes, ears, mouth) Using a variety of media and learning resources. Media and learning resources can be derived from the natural environment or materials that deliberately prepared (Permendikbud 2002: 7).

\section{The formulation of this research is as follows.}

1. What is the ability of early education teachers?

2. How to develop the character of an early child?

3. What is the influence of the environment on the development of early childhood character?

\section{Foccus Issue}

The problem in development research focuses on developing character in the environment for early childhood education 


\section{METHOD}

In this study, the method used is descriptive method. According Nawawi, H. (2007) "descriptive method can be interpreted as a troubleshooting procedure investigated by describing or depicting the state of the subject or object of research (a person, institution, community, etc.) at the present time based on the facts that seem". Through this method, researchers intend to describe the phenomena that occur relating to the naturalist intelligence about the neighborhood preschool children aged 5-6 years in. Furthermore, this study used a qualitative approach. According MoleongLexy J. (2007) is a qualitative approach research procedure that produces descriptive data is data written or oral, and the observed behavior of the people who became the object of research.

Subjects in this study included teachers, principals, parents and children aged 5-6 years in group B of 16 people, consisting of four boys and twelve girls. Teachers group B as the primary informant in obtaining data. In this study, researchers used several data collection techniques, among others: direct communication techniques, direct observation techniques, the techniques of documentary studies. Data collection tools in this study are as follows: interview guidelines, a list of guidelines for observation, documentation of data, field notes.

In the case of qualitative data analysis according Moleng in HeriJauhari (2010) states that "Data analysis is the process of systematically searching for and compiling data obtained from interviews, field notes, and documentation with how to organize data into categories, describe into unit- units, synthesize, organize into a pattern, choose what is important and that will be studied, and make inferences that easy to understand by researchers and others. How to analyze qualitative data is by organizing, sorting, classifying, coding and meaning. In analyzing the data by Miles and Huberman, the Sugiyono (2008) consists of four flow of activities, namely: data collection once data reduction, data presentation, and conclusion drawing / verification.

\section{RESULTS AND DISCUSSION}

This research was conducted in kindergarten MiftahulJannah, which is located at JL. Trunk Quiz Deli Serdang. TK MiftauhJannah was established on February 7, 1953 is the first foundation organizes Kindergarten (TK). Step-by-step lesson on Environment Naturalist intelligence activities in the Preschool Age Children 5-6 Years in kindergarten MiftahulJannah Deli Serdang. Step-by-step implementation of learning naturalist intelligence about the preschool environment that is before teachers begin learning activities to develop naturalist first teachers prepare RPPH (Implementation Plan Daily Activities), RPPH it contains matters related themes, discussions and learning activities related to the theme as it is today relating to the theme of nature that is highly correlated with the naturalist intelligence, setting up the room is conducive, clean and comfortable, the materials / media that will be used by teachers.

Give a fillip to the child through a small game or gymnastics with the song, just stimulate children to drive the motor. Conversing greet children and answering questions based on the theme. In this activity, naturalist there are other methods that support these activities, for example at the beginning of the learning that has been mentioned above, such as the method in conversation first in introducing the object and nature of, chatted to explore the knowledge of children, to train children to express what they know and to know children's understanding of activities that will be carried out for example the activities picking up trash, to introduce to children around the existing plant preschool environment. Then the method of assignment either individually or in groups for children to better understand and further hone the ability of children, giving tasks such as coloring, filling an existing worksheet in magazines and others that in addition to hone children's knowledge, also hone motor skills, cognitive, and assist the development of other aspects as well.

All planned into one package in RPPH tailored to the theme of the day in accordance with the K13 curriculum. From the observation that has researchers do can be seen steps in the activities of intelligence naturalist about preschool environment is as follows: 1) Master makes SOP 2) .Guru make RPPH (Learning Plan DailyProgrammer) related activities naturalist intelligence, especially events learning about the naturalist intelligence is always inserted at the beginning of the core activities and further applied to these activities teachers plan on the second and third events. 3) Before starting the activities, the teacher always conditioned the pleasant atmosphere, for example, before the activity starts first teacher taking children conversing activities to be carried out which learning activities to develop naturalist how protecting the environment to stay clean and beautiful, singing, gymnastics, and etc.4) In the next process while the steps children are introduced first to the media / equipment / materials for activities, then the teacher explains and gives examples of what will be done every stage of its activities, teachers also provide opportunities for children to ask what is not yet clear and 
understand the child. What Ivedia used Oniy in the Activity lvaster characteron Environment Developming Preschool in Children Aged 5-6 Years in early childhood teacher .And media used in the naturalist intelligence activities on the environment preschool children aged 5-6 years in kindergarten MiftahulJannah media that used when introducing a form of pictures, all kinds of food coloring, activity drawing paper, used plastic cans, cotton, and sprouts.

Not all media purchased by teachers there also are made from ingredients used in the form of scrap plastic cups collected children drink teachers because any time to the media or material useful when done. Beside that scrap materials that teachers use a display media such as pictures of various types animals, drawing children to protect the environment in order to keep clean and beautiful. There is also a media / other games that support the naturalist in children of observing the environment and plant growth directly to add knowledge to the children how the origin of plant growth from small to grow big by practicing directly to children such as in the study looked at the growth sprouts from the green beans then develop into sprouts child is very enthusiastic about this activity. Know the types of animals through the media picture and introduce children to color mixing. character to teach children more fun children can observe whatever is in the preschool environment as well as protecting the environment to stay clean and healthy, because it makes children very enthusiastic and eager to implement learning activities. So that was not smart child, playing alone or interfere friends became interested and want to join with friends. In addition to the character activities on the environment is very helpful in stimulating children's teachers, instilling the values of intelligence in children from an early age to protect the environment, and loving environment and pets can embed memory to children as early as possible.

From the observation that researchers do, the media used by teachers in the learning activities to develop naturalist intelligence about preschool environment is by media images, a variety of dyes from food, children's activities drawing paper, used plastic cans, cotton, preschool environment directly. The media there are self made using scrap materials and form images were purchased. Media are made by teachers including plastic cups cistern, pictures of animals made by teacher. And than for media support of the activities of this character, such as the defining moment of learning materials, teachers need media such as whiteboards, markers and books / magazine . Media this is used at the beginning of the core activities, the whiteboard is used to draw animals and plants as well as write the first word of which is described by teacher. game with the media also to develop children's knowledge about the environment, motor movement, social, emotional and other child etc. Means and infrastructure in group B looks already put to good use.

\section{What are the Factors Inhibiting and Support in Learning to Develop Character on Environment Preschool in Children Aged 5-6 Years in kindergarten MiftahulJannah?.}

Factors that inhibit the activity of this naturalist intelligence is like supporting media / materials play is still not so much. Sometimes the child spirit and there are some who are not excited, how clever teachers find a way to make children excited and participate. Then factor of parents there are some who are impressed force their children to quickly be able to read, write without regard to the development of their children, so that teachers are often blamed for not teaching children to write and read, but it is all its stages, the child can not be imposed will result in the child who feel burdened and lazy overcome.Teachers way must be clever and creative in creating the game and classifies the other core activities.

Teachers also have to communicate to all of the parents to provide an understanding that each child is different, parents can not force a child should be able to write and read, if you do not want the development of troubled children next time. Where as, factors which support the naturalist intelligence, according to the mother Ida as teacher educators in group B supporting factors in naturalistic intelligence activities, namely in terms of activities directly observe what is around the neighborhood preschool institutions, the media were very simple, systematic and attract the attention of the child so that the child more quickly understand and clever, especially in protecting the environment. Psychological level, concentration of children in activities considered to be good, so as to support the process of naturalist intelligence activities.

As well as parents enthusiastically in support of the naturalist on the environment because it will give a positive memory for the child backwards to come. Meanwhile, according to Sri Winarti mother as teacher assistant can be seen that the factors that support is media, teachers and parents. Due to the media interest and activities that are not boring to make children more excited the children are very happy activities .if learning is done by playing both inside and outside the classroom and observe whatever is in the preschool environment, playing while learning to know how to keep the environment so clean, beautiful and healthy. From the results of the observations researchers did it is known that factors that hinder the naturalist intelligence about the preschool environment, among others, media / tools / materials are lacking or have not varied. 
In tnis case the school and the teachers were graduany supplement or create the main ingreaient lor learning activities. Another obstacle is due to children who are less enthusiastic about learning because more focused on their own activities as well as child health factors also greatly affect the learning activities. However, so far based on the observations of investigators when the activities take place teachers they can overcome these obstacles, so not a problem / obstacle means that causes naturalist intelligence activity is inhibited. Many other alternatives that teachers do in overcoming this example, search for sources of material events of the game and the new activities so that children do not feel bored, sometimes teachers also discuss with the child what the child wants to do on that day, so the child will feel happy and give children the opportunity to express their opinions and choose their own activities. Factors that support the naturalist intelligence activities, namely the First, in media support and interest of children in learning activities.Second, teachers are experienced and excellent in delivering sequential learning, clear tone of voice so that the child can hear what is presented by the teacher. Third, classrooms large enough according to the number of children. Fourth, the level of memory and intelligence of the child is good, so that children understand and can carry out activities properly.Fifth, this activity is assessed and systematic learning easily applied to children, because in accordance with the principle of learning by children last play .Dan sixth, there is effective communication between children and teachers and parents are highly supportive of this naturalist intelligence. Parents greatly assisted if in institutions, children are taught the way of playing that makes children feel happy and not bored to go to kindergarten.

\section{DISCUSSION}

The character about preschool environment for children in kindergarten through habituation MiftahulJannah and children actively involved in play activities both inside and outside the room. Through habituation is expected to do good things like being able to adjust to the environment kindergartens, can keep the environment as taught to him. Playing an exciting activity for children. Through play children can learn many things and develop various aspects of intelligence that can have more than one for each child. Playing provide the right conditions in which to learn and enhance the quality of learning through activities pushed from the inside and have their own children.

Therefore, play activities can not be separated from the activities of children in kindergarten because playing is a place for children to learn a variety of thing. Stepand implementation naturalist learning about preschool environment is the implementation in group $\mathrm{B}$, which consists of the stages of planning , implementation and evaluation. In planning the activities of this naturalist intelligence to prepare teachers RPPH (Daily Lesson Plan) at first and then prepare a foothold environment conducive to children's rooms, as well as the media / tools / materials to be used during learning activities take place. Before starting the learning activities the teacher always makes the classroom atmosphere in favorable circumstances, usually the teacher invites the children to gymnastics, singing or chatting beforehand.With the aim that the material presented will be easily absorbed by children. It can be concluded that the learning plan is a first step in the implementation of an activity that is focused on a particular goal. Proper planning will need to load on a formula that will do the teachers and children in the learning process to reach the goal before the actual activities carried out.

In the first step of this activity, the teacher taking children singing, chatting about the environment around the child and what the child and chatted related to the theme and discussion. The next step is the teacher shows the media that will be used in learning activities and explain step by step activities to be implemented so that children understand and provide opportunities for children to ask .So the implementation of the learning process can be summarized as the interaction between the teacher and the child in order to deliver learning materials the child to achieve learning objectives. Implementation of learning should be guided by what is written in the planning. However, the circumstances faced by teachers in the teaching of having a major influence on the process of learning activities are carried out. Therefore, teachers should know about everything involved, so that they can adapt their behavior in teaching situations faced.Although with media commonly used in teaching activities naturalist intelligence about the school environment on children aged 5-6 years in commonly used method storytelling using books or magazines.

Here, in a different way, namely by habituation and observed the environment around the institution kindergarten and through the game. Media used when introducing a form of pictures, all kinds of food coloring, children's activities drawing paper, used plastic cans, cotton and green beans / seeds. The role of teachers and parents in these activities is to assist the growth and development of children in the best way to build interest, needs, and strengths that exist in every child. Activities are being organized in such a way appropriate to the theme and the discussion of making it easier for children to understand the meaning and facilitate the child remember when the teacher explains activities. Children aimed not only recognize letters but also recognize objects and their benefits and expected through the game as simple a child can keep the environment to stay clean and beautiful. 
Factors innibiting the activity of character is IIKe supporting media / materlais that do not play so much. Sometimes the child spirit and there are some children who are not excited, teachers should be good at seeking ways to make children excited and participate, because it still looks children are preoccupied with themselves or playing with friends when activity. Then factor of parents are still some who impressed force their children to quickly be able to read, write without regard to the development of their children, so that teachers are often blamed for not teaching their children to read and write, whereas all the existing stages, the child can not be imposed as it would result in the child who feel burdened and lazy. Through a simple play in becoming acquainted with the types of animals and children are introduced early letters through the images / media used by teachers

The fix must be clever and creative teachers in creating games and classify them with other core activities. Teachers also have to communicate to all of the parents to provide think. that every child is different, parents can not force children to be able to write and read, if you do not want the development of troubled children. Naturalist intelligence activity supporting factor, among others, can be studied in directly what is in the neighborhood kindergarten, media were very simple systematic and attract children's attention more quickly understand and clever, especially in maintaining a pleasant environment when applied to children, because in accordance with the principle of the child, citing Mayesty that "for child, play is that they do all day for the children to play is life and life is a game "(in Sujiono, 2009).

Psychological level, concentration of children in activities considered to be good, thus supporting the naturalist intelligence activities. And parents enthusiastically.in support of the naturalist intelligence about the activities of the environment because it will give a positive memory for the child backwards to come. With media interest and not boring to make children get excited about learning. Moreover, children are very happy if learning is done by playing well done inside and outside the classroom and observe whatever is in the preschool environment, play while learning can figure out how to keep environment clean, beautiful and healthy.

\section{CONCLUSIONS AND SUGGESTIONS}

In connection with research conducted in kindergarten MiftahulJannah it can be concluded from the results of observation, interviews, documentation and record qualitative field. The conclusions that can be drawn by the researchers is as follows: 1) Steps in activities naturalist intelligence are first setting up RKH (Plan Daily Activities), footing environments such as teachers prepare the rooms were conducive, clean and media / materials / tools playbooks, At the beginning teachers did carry on a conversation. And than teachers do learning activities with naturalist intelligence activities on the environment. 2) The media used by teachers in the naturalist intelligence activities on the environment is very diverse variety of food dyes, plastic containers, drawing the kinds of animals, activities drawing paper, cotton, bean sprouts / mung bean. Not all media created their own teachers there also purchased.All media that children use very attract children, safe, varied not monotonous, adapted to the curriculum and Dikbud 137 Candies and Sweets Dikbud 2014146 2014. 3) The factors inhibiting naturalist intelligence activities, namely as a supporting medium / materials that do not play so much. Sometimes the child spirit and there are some children who are not excited, teachers should be good at seeking ways to make children excited and participate, because it still looks children are preoccupied with themselves or playing with friends when activity. The factors supporting the activities of naturalist intelligence, among others, can observe directly what is in the neighborhood kindergarten, media were very simple systematic and attract children's attention more quickly understand and clever, especially in maintaining a pleasant environment when applied to children , because in accordance with the principle of the child.

\section{Suggestion}

In accordance with the above conclusion, the next as their contributions to the TK MiftahulJannah to the input of the results of this study, the researchers wanted to convey some suggestions, as follows: 1) Teachers are expected to further increase creativity in presenting activities or games for children, so that seemed to be monotonous and boring. So that they can learn more and get a different experience each game as well as various aspects of child development can be achieved according to the age and development tasks. 2) We recommend that teachers need to consider both the tools of games available outdoors for safety and comfort of children in the play as well as introduce to the children about keeping the environment clean. 3) Teachers and parents more frequent communication and face-to-face to discuss the issues and child development. If only once in a month can be increased to two or three meetings a month because the sooner parents know the problems experienced by children it will be sooner diatasinya.4) In order to further develop the naturalist intelligence of children in kindergarten, the teacher should add APE and the main ingredient in the classroom, so that children are more rich 
In creativity educate and develop the naturalist inteningence can be ennanced more.s) Encourage child to participate in or observe things that are outside of the classroom so that children can develop insights on the environment and natural surroundings.

\section{RUJUKAN}

Hasan, Maimunah. 2012. ECD (Early Childhood Education) .Jogyakarta: DIVA Pres (Member IKAPI). Jauhari, Heri. 2010. Free Thesis Writing Theory and Aplikasi.Bandung: PustakaSetia CV.

Moleong, Lexy J. 2007. Qualitative Research Methodology. Bandung: Youth Rosdakarya.

Nawawi, Hadari. 2007. Methods Field Sosial.Yogyakarta.GajahmadaUnervisity Press.

Sujiono, Yuliani Conscience. 2009. Basic Concept of Early Childhood Education. Jakarta: PT. Index.

Sugiyono. 2008. Methods of Educational Research. Bandung: Alfabeta.

Soefandi, Indra, \& S. Ahmad Pramudya.2009. Strategi Developing Potential Child Intelligence. Jakarta: Indonesia Bee Media. 